Article

\title{
A Deferasirox Derivative That Acts as a Multifaceted Platform for the Detection and Quantification of $\mathrm{Fe}^{3+}$
}

\author{
Axel Steinbrueck, Adam C. Sedgwick, Suh-Mi Hwang, Sajal Sen, Michael Y. Zhao, Dan-Ying Huang, \\ Daniel M. Knoll (D), Yu-Ying Wang and Jonathan L. Sessler*
}

\section{check for}

updates

Citation: Steinbrueck, A.; Sedgwick, A.C.; Hwang, S.-M.; Sen, S.; Zhao,

M.Y.; Huang, D.-Y.; Knoll, D.M.;

Wang, Y.-Y.; Sessler, J.L. A Deferasirox

Derivative That Acts as a

Multifaceted Platform for the

Detection and Quantification of $\mathrm{Fe}^{3+}$.

Chemosensors 2021, 9, 68.

https://doi.org/10.3390/

chemosensors 9040068

Academic Editor: Run Zhang

Received: 15 February 2021

Accepted: 25 March 2021

Published: 30 March 2021

Publisher's Note: MDPI stays neutral with regard to jurisdictional claims in published maps and institutional affiliations.

Copyright: (C) 2021 by the authors. Licensee MDPI, Basel, Switzerland. This article is an open access article distributed under the terms and conditions of the Creative Commons Attribution (CC BY) license (https:/ / creativecommons.org/licenses/by/ $4.0 /)$.
Department of Chemistry, The University of Texas at Austin, 105 E 24th Street A5300, Austin, TX 78712-1224, USA; axel.steinbrueck@utexas.edu (A.S.); Adamsedg@illinois.edu (A.C.S.); ghsm0311@gmail.com (S.-M.H.); sajal@utexas.edu (S.S.); myzhao@utexas.edu (M.Y.Z.); danyinghuang@utexas.edu (D.-Y.H.); dmk.knoll@gmail.com (D.M.K.); yuying@utexas.edu (Y.-Y.W.)

* Correspondence: sessler@cm.utexas.edu

Abstract: Here, we report that $\mathrm{ExSO}_{3} \mathrm{H}$, a synthetically accessible, water-soluble, non-toxic derivative of the clinical iron chelator deferasirox, acts as a colorimetric chemosensor that permits the detection and quantification of $\mathrm{Fe}^{3+}$ in aqueous samples at $\mathrm{pH}$ 2-5. In addition, we observed that a fluorescent turn-on response was produced when this chelator was allowed to interact with human serum albumin (HSA). This fluorescence was quenched in the presence of $\mathrm{Fe}^{3+}$, thus allowing us to monitor the presence of this biologically important metal cation via two independent methods.

Keywords: deferasirox; iron chelation; chemosensor; water samples

\section{Introduction}

The selective detection and reliable quantification of metal cations in aqueous samples is a critical aspect of analytical chemistry. It serves, for instance, to ensure that quality standards set by regulatory bodies, such as the World Health Organization (WHO), are met for drinking water and food [1,2]. These needs are providing an incentive to develop fast, reliable and inexpensive analytical methods that meet the sensitivity and detection limits associated with these and other quality standards. Iron, the most abundant transition metal in the earth's crust, is a key micro-nutrient due to its structural role in biology and its presence as a cofactor in a plethora of enzymes and proteins. Iron, in formal oxidation states ranging from $\mathrm{Fe}^{2+}$ to $\mathrm{Fe}^{5+}$, is involved in numerous vital processes including but not limited to oxygen transport and storage, energy generation within the mitochondria, drug metabolism, and DNA synthesis [3-6]. In normal non-biological milieus, the dominant oxidation state for iron is $\mathrm{Fe}^{3+}$, a species whose solubility is highly dependent on $\mathrm{pH}$ due to the formation of poorly soluble $\mathrm{Fe}^{3+}$ oxide- and hydroxide species, e.g., $K_{\mathrm{sp}}$ for $\mathrm{Fe}(\mathrm{OH})_{3} \approx 10^{-40}$ [4]. However, matrix effects such as the presence of oxalates, salicylates and humic acids have been reported to increase the solubility of $\mathrm{Fe}^{3+}$ in real-life water samples [7-9].

In the laboratory, the concentrations of heavy metals, such as cadmium, arsenic and lead, are frequently quantified via flame atom absorption spectroscopy (FAAS) due to the low costs, the small sample size requirements, and the fast response times associated with this method [10]. However, the reliable quantification of iron cations in real-life water samples via FAAS at or below the WHO recommended limit of $0.3 \mathrm{ppm}(=0.3 \mathrm{mg} / \mathrm{L}$ or $5.4 \mu \mathrm{M})$ requires laborious preconcentration due to the low concentration of $\mathrm{Fe}^{3+}$ which lie well below the detection limit of FAAS for this particular cation [11]. In addition to this shortcoming, the unpredictable impact of matrix effects further limits the utility of FAAS as an analytical method for the quantification of iron cations in water samples [12]. Other instrumental methods that have been explored for iron detection include inductively coupled plasma mass spectrometry (ICPMS), $[13,14]$ inductively coupled plasma atomic emission 
spectroscopy [15], potentiometry [16] and voltammetry [17]. However, these techniques are either expensive, require costly instrumentation, or are time consuming to conduct when analyzing multiple samples. In an effort to overcome these drawbacks, researchers have focused on the development of spectrophotometric chemosensors that allow for the rapid determination of iron content in water samples using colorimetric [18-28] and fluorescentbased $[21,23,27-34]$ means. However, many of these systems require the use of organic co-solvents, such as chloroform or acetic acid. Moreover, as a general rule, existing iron chemosensors are relatively challenging to access synthetically; many also depend on chemical motifs that are inherently toxic, such as rhodamine [35].

Chelators that display binding selectivity towards the ferric iron have been in clinical use for a number of decades as treatments for iron overload disease [4]. Deferasirox (1) is an U.S. Food and Drug Administration (FDA) approved iron chelator that possesses a high binding affinity for ferric iron ( $\log \beta=36.9$ for the 2:1 ligand-metal complex) [36] and benefits from selectivity over other biologically relevant metal cations. Interestingly, $\mathbf{1}$ is known to form a distinct, pink colored 1:1 ligand-metal complex with $\mathrm{Fe}^{3+}$, particularly in organic solvents [36]. In water, however, $\mathbf{1}$ has been reported to form both 1:1 and 2:1 complexes with $\mathrm{Fe}^{3+}$. These two species have different spectral features. Moreover, their actual distribution is a sensitive function of $\mathrm{pH}$. As a consequence, tight control over the $\mathrm{pH}$ is required if $\mathbf{1}$ is to be used for the quantitative determination of $\mathrm{Fe}^{3+}$ in water [36]. Further complicating matters is the hydrophobicity of $\mathbf{1}(\log \mathrm{P}=3.8)$; this results in poor water solubility and further limits its utility as a $\mathrm{Fe}^{3+}$ chemosensor [37]. Recognizing these limitations, we focused our efforts on evaluating the sulfonic acid-bearing deferasirox derivative, $\mathbf{2}$, as a potential $\mathrm{Fe}^{3+}$ chemosensor. The strategic introduction of sulfonic acid groups to enhance the water solubility of chemosensors has been explored previously $[38,39]$. The introduction of this functional group has also been reported to reduce the cytotoxicity of small molecules [40,41]. As true for 1, the distribution between the 1:1 and 2:1 complexes of 2 with $\mathrm{Fe}^{3+}$ in water favors predominantly the 1:1 complex below pH 5 (vide infra) [36]. We thus thought that 2 could emerge as a chemosensor for $\mathrm{Fe}^{3+}$ that would permit the naked-eye detection and spectrophotometric quantification of $\mathrm{Fe}^{3+}$ in aqueous samples. This study was undertaken in an effort to test this hypothesis.

\section{Materials and Methods}

\subsection{Synthesis}

Deferasirox (1) and the sulfonic acid bearing derivative $\mathrm{ExSO}_{3} \mathrm{H}(2)$ were synthesized on the decagram scale from commercially available reactants and in good yield following a simple two-step procedure that was adapted from the literature (cf. Supplementary Materials Scheme S1) [36].

Detailed synthetic procedures and analytical data verifying the identity and purity of all prepared compounds can be found in the supporting information (ESI). The reported ${ }^{1} \mathrm{H}$ NMR and ${ }^{13} \mathrm{C}$ NMR spectra were measured on Varian Inova spectrometers at The University of Texas at Austin using $\mathrm{CDCl}_{3}$ and DMSO- $d_{6}$ as the deuterated solvents. Chemical shifts are reported relative to the residual solvent proton signals. For the spin multiplicities, the following abbreviations were used: $s$ (singlet), $d$ (doublet), $t$ (triplet), $q$ (quartet), and $\mathrm{m}$ (multiplet), as well as appropriate combinations of these. Coupling constants for protons $(J)$ are given in Hertz $(\mathrm{Hz})$. The NMR spectra were analyzed using the software MestReNova v.10.0.2-15465 (Mestrelab Research S.L., Santiago de Compostela, Spain). All deuterated solvents were purchased from Cambridge Isotope Laboratories (Tewksbury, USA). High-resolution electrospray ionization (ESI) mass spectra were recorded on a VG ZAB2E instrument or VG AutoSpec apparatus.

\subsection{Chemicals}

All materials were obtained from commercial sources at the highest purity available and used without further purification. Reactions were carried out under air unless otherwise specified. Flash column chromatography was performed on Sorbent silica gel 
(40-63 $\mu \mathrm{M})$. Analytical thin layer chromatography (TLC) analyses were carried out using glass-backed silica gel plates ( $200 \mu \mathrm{M}$, Sorbent Technologies, Norcross, GA, USA).

\subsection{Water Samples}

Stream water was collected on Tuesday 23 July 2019, 11 a.m. from a local stream in Austin at $30^{\circ} 17^{\prime} 13.9^{\prime \prime} \mathrm{N}, 97^{\circ} 44^{\prime} 02.7^{\prime \prime} \mathrm{W}$. Tap water was collected on Wednesday 8 July 2019 , 4 p.m. from a tap inside the Sessler Group Labs on the 5th floor of the Norman Hackerman Building at 105 E 24th Street, Austin, TX, 78712 (USA).

\section{4. $p H$ Determination}

$\mathrm{pH}$ measurements were performed at $20^{\circ} \mathrm{C}$ on a calibrated Accumet ${ }^{\circledR}$ AE- $150 \mathrm{pH}$ meter with a glass combination $\mathrm{pH}$ and oxidation-reduction potential (ORP) titration electrode $(\mathrm{Ag} / \mathrm{AgCl}$ in sat. $\mathrm{KCl}$ as the internal reference) and a temperature sensor.

\subsection{Spectroscopy}

UV-Vis spectra were recorded on a Varian Cary 5000 UV-Vis-NIR Spectrophotometer. A baseline correction was performed with the corresponding blank (pure solvent) before each spectrum was taken. Fluorescence spectroscopic measurements were made using an Agilent Cary Eclipse fluorescence spectrofluorometer. The emission and excitation slit widths were fixed at $5 \mathrm{~nm}$ unless otherwise specified. Emission spectra were recorded using an excitation wavelength of $330 \mathrm{~nm}$ unless otherwise specified. Where applicable, appropriate blanks were subtracted from the spectra.

\subsection{Cell Experiments}

A549 cells were obtained from the American Type Culture Collection (ATCC, Manassas, VA, USA) and maintained in an RPMI-1640 Medium (Sigma, St. Louis, MO, USA) supplemented with $10 \%$ fetal bovine serum (FBS, Sigma, St. Louis, MO, USA) and $2 \%$ Penicillin/Streptomycin (P/S, Sigma, St. Louis, MO, USA) in a humidified atmosphere of $5 \% \mathrm{CO}_{2}$ and $95 \%$ air at $37{ }^{\circ} \mathrm{C}$. Cells were split when they reached $90 \%$ confluency. Absorbance values for the 3-(4,5-dimethylthiazol-2-yl)-2,5-diphenyltetrazolium bromide (MTT) assay were measured at $540 \mathrm{~nm}$ with an M5 microplate reader (Molecular Device, Sunnyvale, CA, USA). Linear regression analyses were performed in Origin 2019b (OriginLab, Northampton, MA, USA).

For the MTT assay, A549 cells were harvested and plated on a 96-well plate in $100 \mu \mathrm{L}$ growth medium at a density of 1500 cells per well. The cells were left to grow overnight in an incubator at $37^{\circ} \mathrm{C}$ under $5 \% \mathrm{CO}_{2}$ atmosphere for $24 \mathrm{~h}$. The next day, appropriate concentrations of the compound under investigation were prepared via three-fold serial dilution in growth medium, and $100 \mu \mathrm{L}$ was added to each row of wells. Herein, the highest concentration of compound that was evaluated was $250 \mu \mathrm{M}$. Two rows of wells were treated with only $100 \mu \mathrm{L}$ medium as reference. After further incubation for $72 \mathrm{~h}, 3 \mathrm{mg} / \mathrm{mL}$ MTT dye was dissolved in FBS- and P/S free medium and $50 \mu \mathrm{L}$ of this MTT solution was added to each well. After an additional incubation for $4 \mathrm{~h}$, the supernatant was carefully removed and $50 \mu \mathrm{L}$ of DMSO was added to each well to solubilize the precipitated formazan dye. The optical density was measured for each well and a dose-response curve was produced from the mean absorbance of each row of wells, which was normalized to the wells containing untreated cells to allow for plate-to-plate comparison. The dose-response curves were subjected to linear regression analysis to determine the half maximum inhibitory concentration $\left(\mathrm{IC}_{50}\right)$ values. Data are shown as the mean of 3 replicate experiments and error bars represent the standard deviation.

\section{Results and Discussion}

In the presence of $\mathrm{Fe}^{3+}$ in water at $\mathrm{pH}=3$, both $\mathbf{1}$ and $\mathbf{2}$ show a distinct absorption peak with an absorbance maximum around $510 \mathrm{~nm}$ in the visible spectral region, as shown in Figure 1a. However, chemosensor 2 produces a more readily visible coloration and 
gives rise to a greater absorbance at $510 \mathrm{~nm}$ with respect to 1 . We thus went on to evaluate the sensitivity of $\mathbf{2}$ to changes in $\mathrm{pH}$. Towards this end, aqueous acetate buffer solutions of $\mathrm{pH} 2-5$ were prepared and the absorbance at $510 \mathrm{~nm}$ was measured for solutions that were $30 \mu \mathrm{M}$ in both $\mathrm{Fe}^{3+}\left(\right.$ as $\mathrm{FeCl}_{3}$ ) and 2, respectively, over the course of $50 \mathrm{~min}$. The results, shown in Figure 1c, reveal that 2 yielded a reproducible response over the 2-5 pH range. Moreover, the measured absorbance at $510 \mathrm{~nm}$ was found to increase rapidly until reaching a constant plateau after 3-9 min depending on the $\mathrm{pH}$. At $\mathrm{pH}=3$ and $\mathrm{pH}=4$, we observed a similar absorbance at $510 \mathrm{~nm}$ after only 3 min incubation time, which remained constant. At $\mathrm{pH}=2$, a constant absorbance was measured after 5 min incubation time; however, at all time points the absorbance value was below that measured at $\mathrm{pH}=3$. At $\mathrm{pH}=5$, we observed the highest absorbance among the evaluated $\mathrm{pH}$ levels after an incubation time of $9 \mathrm{~min}$. However, at $\mathrm{pH}=5$ the intensity grew comparatively slowly and remained less consistent over time as compared to what was seen at $\mathrm{pH}=3$. These findings indicated to us that each of the evaluated $\mathrm{pH}$ levels would be advantageous in some aspect for further exploration of $\mathbf{2}$ as a colorimetric chemosensor. To ensure consistency, $\mathrm{pH}=3$ was used for further experiments, in part because this $\mathrm{pH}$ value would allow for a direct comparison to 1, which at this $\mathrm{pH}$ also supports the predominant formation of a 1:1 complex [36].
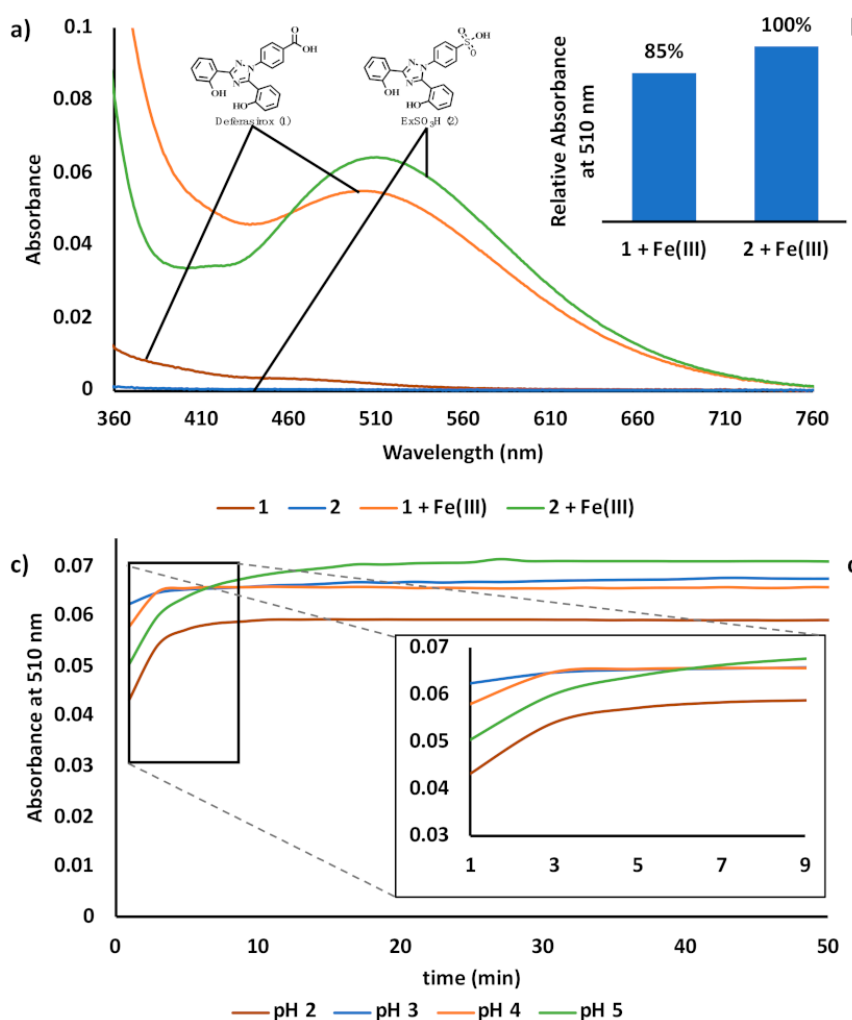

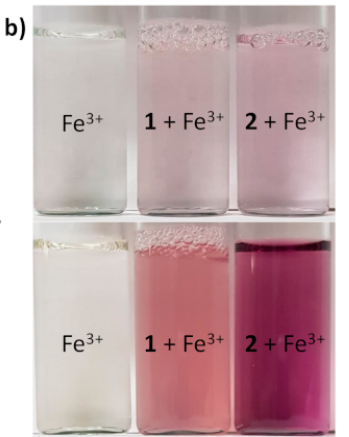

$30 \mu \mathrm{M}$ in each species (top) $200 \mu \mathrm{M}$ in each species (bottom)

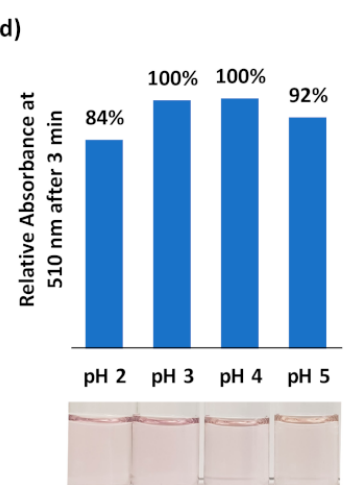

Figure 1. (a) Absorbance spectra of 1 and 2 (both at $30 \mu \mathrm{M}$ ) in the absence and presence of one molar equivalent of $\mathrm{Fe}^{3+}$ in acetate buffer at $\mathrm{pH}=3$. (b) Photos of $\mathrm{FeCl}_{3}$ in the absence and presence of 1 or 2 at $30 \mu \mathrm{M}$ and $200 \mu \mathrm{M}$ at $\mathrm{pH}=3$, respectively. (c) Time profile of the absorbance at $510 \mathrm{~nm}$ for $30 \mu \mathrm{M}$ 2 and $30 \mu \mathrm{M} \mathrm{Fe}^{3+}\left(\right.$ as $\left.\mathrm{FeCl}_{3}\right)$ in aqueous acetate buffer solutions at the indicated $\mathrm{pH}$. (d) Relative absorbance at $510 \mathrm{~nm}$ after incubating for $3 \mathrm{~min}$ in an acetate buffer at the indicated $\mathrm{pH}$ (top) and pictures of the corresponding solutions (bottom).

To assess the binding stoichiometry between 2 and $\mathrm{Fe}^{3+}$, we employed the method of continuous variation (Job plot analysis), which yielded an absorption maximum at a mole fraction of 0.5 as expected for a 1:1 binding stoichiometry (Figure 2a,b). 

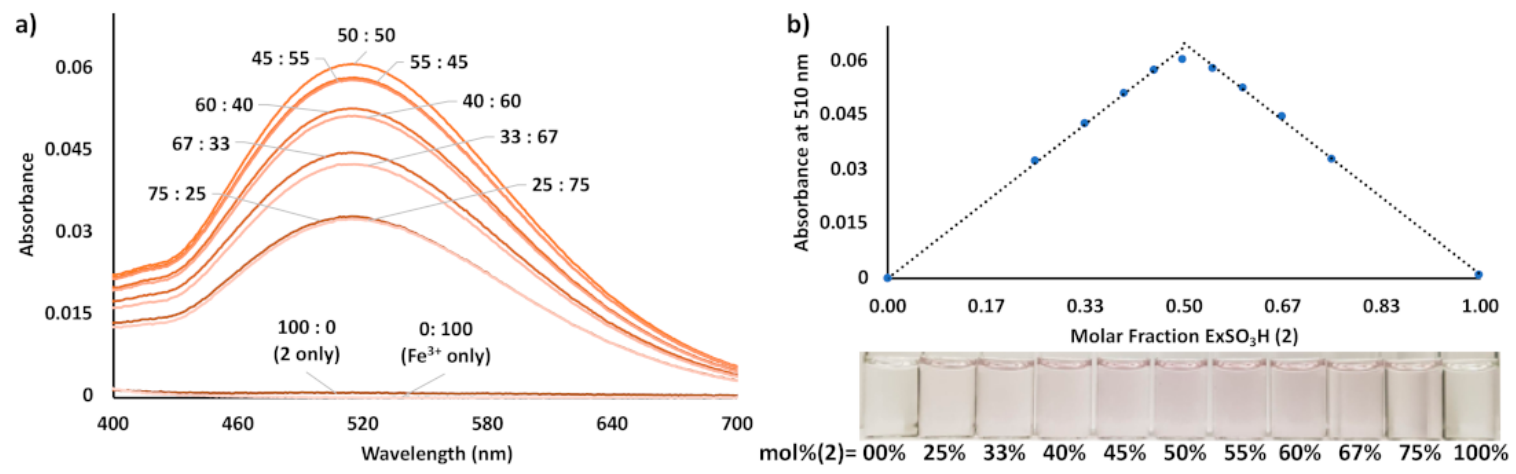

Figure 2. (a) Absorbance profiles of varying ratios of 2 and $\mathrm{Fe}^{3+}\left(\right.$ as $\left.\mathrm{FeCl}_{3}\right)$ indicated as $\mathrm{mol} \%$ 2: $\mathrm{Fe}^{3+}$ in $0.1 \mathrm{M}^{2}$ aqueous acetate buffer at $\mathrm{pH}=3$ with the sum of both species $=50 \mu \mathrm{M}$ at each datum point. (b) Corresponding Job's plot of the absorbance at $510 \mathrm{~nm}$ of 2 and $\mathrm{Fe}^{3+}$. A maximum in the absorbance intensity is seen at a mole fraction $=0.5$, a finding consistent with a 1:1 binding ratio.

The titration of $\mathbf{1}$ and $\mathbf{2}$ with $\mathrm{Fe}^{3+}$ in a $0.1 \mathrm{M}$ aqueous acetate buffer at $\mathrm{pH} 3$ yielded a linear concentration dependent increase in the absorbance intensity at $510 \mathrm{~nm}$ in the case of 2 . The response became non-linear after 1 equivalent of $\mathrm{Fe}^{3+}(30 \mu \mathrm{M})$ had been added, a finding consistent with the proposed 1:1 binding mode. Less ideal behavior was seen for chelator $\mathbf{1}$, as can be seen from an inspection of Figure 3. From the titration data, the association constants $\left(K_{\mathrm{a}}\right)$ for the 1:1 metal-ligand complexes of $\mathbf{1}$ and $\mathbf{2}$ with $\mathrm{Fe}^{3+}$ could be estimated via a non-linear regression analysis [42]. We also calculated the limit of detection (LOD) using the following formula: $\mathrm{LOD}=3 \times \mathrm{SD}_{\mathrm{b}} \times \mathrm{m}_{\mathrm{x}}{ }^{-1}$ (where $\mathrm{SD}_{\mathrm{b}}=$ standard deviation of the blank and $\mathrm{m}_{\mathrm{x}}=$ slope of the titration curve). The results obtained in this way (cf. Figure 3) provided support for the inference drawn on the basis of the colorimetric studies, namely that 2 constitutes the more sensitive chemosensor for $\mathrm{Fe}^{3+}$. In fact, at $\mathrm{pH} 3$, sensor 2 permits the quantification of $\mathrm{Fe}^{3+}$ in water with a $\mathrm{LOD}=0.24 \mu \mathrm{M}$ vs. ca. $0.30 \mu \mathrm{M}$ for 1 . Due to the nonlinear nature of the response seen with 1 , the latter value should be treated as being an estimate. Based on these findings, we conclude that 2 may be employed as a chemosensor for the quantification of $\mathrm{Fe}^{3+}$ within the $0.24 \mu \mathrm{M}$ to $30 \mu \mathrm{M}$ concentration regime where linear response behavior is seen.

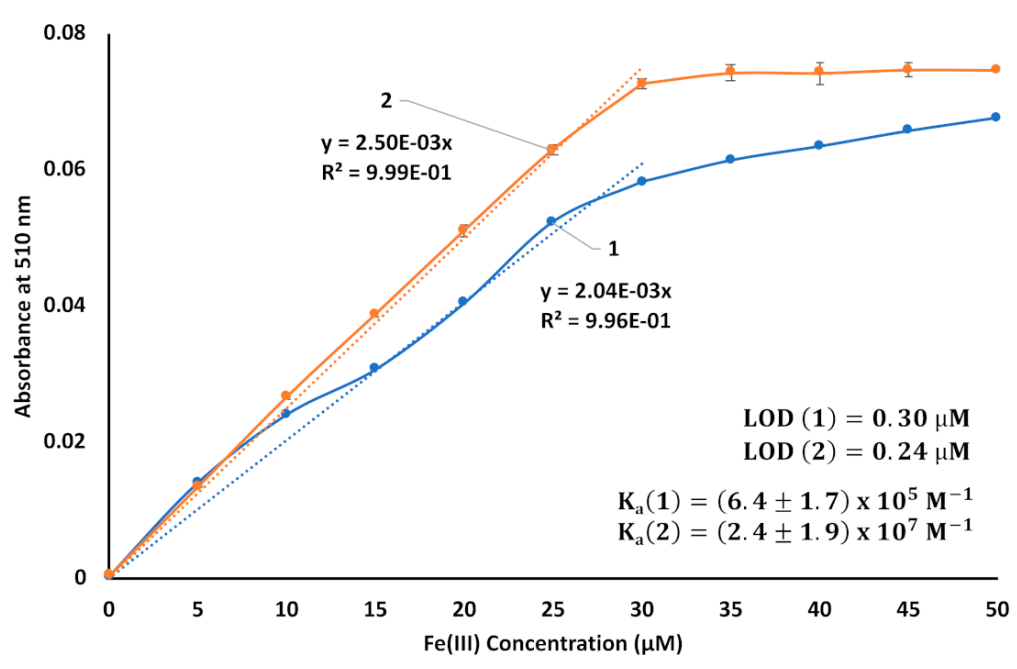

Figure 3. Titration of $\mathbf{1}$ and $\mathbf{2}$ with $\mathrm{Fe}^{3+}$ in $0.1 \mathrm{M}$ acetate buffer at $\mathrm{pH}$. The chelator concentration was held constant at $30 \mu \mathrm{M}$. The inset gives the association constants $\left(K_{\mathrm{a}}\right)$ corresponding to the formation of the 1:1 complexes, along with the limits of detection (LODs) determined using the following equation: $\operatorname{LOD}(\mathrm{x})=3 \times \mathrm{SD}_{\mathrm{b}} \times \mathrm{m}_{\mathrm{x}}{ }^{-1}$ where $\mathrm{SD}_{\mathrm{b}}=$ standard deviation of the blank and $\mathrm{m}_{\mathrm{x}}=$ the slope of the titration curve. 
A screen of nine different divalent and trivalent metal cations revealed that only $\mathrm{Fe}^{3+}$ produced an appreciable color change with chemosensor 2 as shown in Figure 4. In the case of $\mathrm{Mn}^{2+}$ and 2, an absorbance feature at $510 \mathrm{~nm}$ was seen at high concentrations; however, at the same $50 \mu \mathrm{M}$ concentration where $\mathrm{Fe}^{3+}$ produced a response, no visible coloration was seen in the case of $\mathrm{Mn}^{2+}$. Notably, the presence of $\mathrm{Cu}^{2+}, \mathrm{Al}^{3+}$ and $\mathrm{Fe}^{2+}$, all potential interferants for an $\mathrm{Fe}^{3+}$ binding motif, did not produce any visible discoloration nor a measurable absorbance at $510 \mathrm{~nm}$.
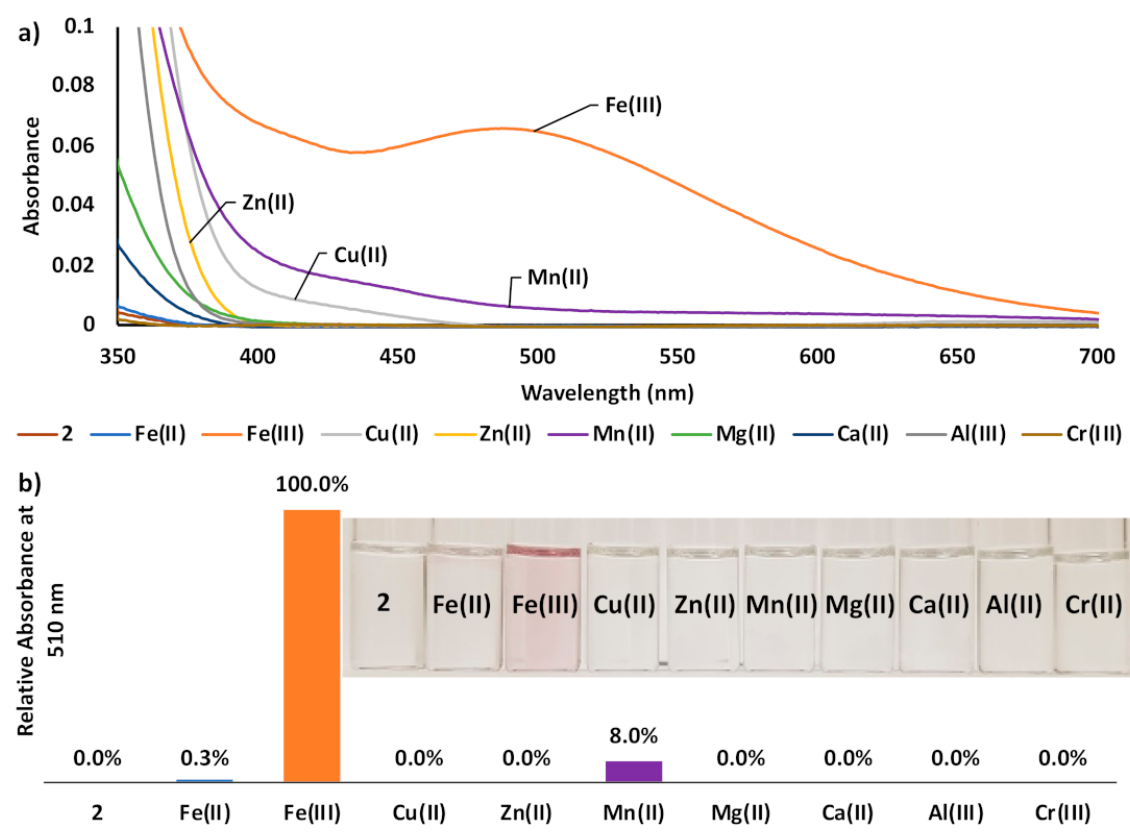

Figure 4. (a) Absorbance spectra of $30 \mu \mathrm{M} 2$ recorded in the presence of $50 \mu \mathrm{M}$ of various test diand trivalent metal cations in water at $\mathrm{pH}$ 3. (b) Relative absorbance at $510 \mathrm{~nm}$ for each metal cation solution and photos of the corresponding samples.

We went on to evaluate the performance of 2 as an $\mathrm{Fe}^{3+}$ colorimetric chemosensor in a tap water sample (S1) and a stream water sample (S2), with the results being shown in Figure 5. The addition of $50 \mu \mathrm{M} 2$ produced only a small absorbance at $510 \mathrm{~nm}$ for each sample, respectively. To verify the effectiveness of $\mathbf{2}$ as a colorimetric sensor and to assess the impact of matrix effects, we then added $30 \mu \mathrm{M} \mathrm{Fe}^{3+}$ to each sample and compared the response to a positive control containing $30 \mu \mathrm{M} \mathrm{Fe}^{3+}$ and $50 \mu \mathrm{M} 2$ in pH 3 buffer solution. Due to the basic $\mathrm{pH}$ of each water sample $(\mathrm{pH}>8)$, the addition of $\mathrm{Fe}^{3+}$ produced a shallower absorbance curve than might have been expected for each water sample. Thus, we explored prior acidification of each sample to $\mathrm{pH} 3$ by adding adequate amounts of $0.01 \mathrm{M} \mathrm{HCl}$. Under these conditions, the addition of $30 \mu \mathrm{M} \mathrm{Fe}^{3+}$ resulted in the expected proportional increase in absorbance at $510 \mathrm{~nm}$ and gave a signal commensurate with the positive control. These results lead us to suggest that after $\mathrm{pH}$ adjustment, matrix effects do not significantly impact the efficacy of $\mathbf{2}$ in real-life water samples. 

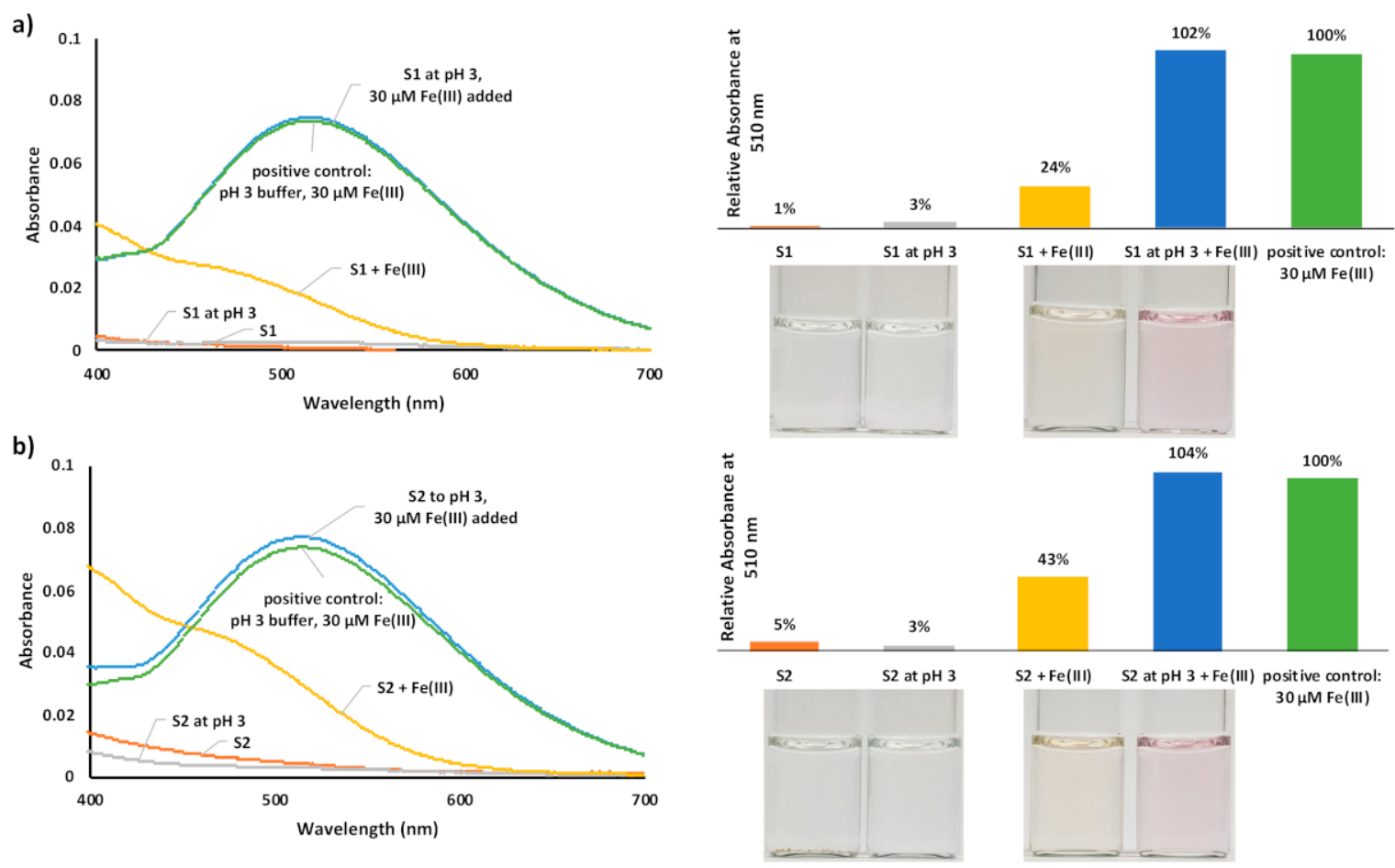

Figure 5. Evaluation of $\mathbf{2}$ in samples of (a) tap water (S1) and (b) stream water (S2). Samples are shown prior to and after acidification to $\mathrm{pH}$ 3. The spectra are shown to the left and the relative absorbance at $510 \mathrm{~nm}$ for each sample is shown in the bar charts to the right. The control samples were made up at $\mathrm{pH} 3$ in an acetate buffer.

We have recently found that the strategic functionalization of $\mathbf{1}$ provides access to chelators that show fluorescent behavior in aqueous media via a fluorescence mechanism that involves aggregation induced emission (AIE) [43]. It was thus thought that the measurement of the putative AIE fluorescent emission intensity might provide a means of quantifying the concentration of $\mathbf{2}$ in aqueous samples. Unfortunately, the sulfonated derivative 2 did not produce a detectable fluorescent signal in acetate buffer at $\mathrm{pH} 3$ or in deionized water at $\mathrm{pH} 5.5$ after addition, respectively, a finding that we attribute to this particular chelator having a relatively high water-solubility with respect to other deferasirox-derivatives, including 1 . High water solubility is expected to militate against aggregation and preclude an AIE effect. This perceived limitation was overcome by adding human serum albumin (HSA) to solutions of $\mathbf{2}$ in deionized water. Deionized water was employed to avoid both the acid catalyzed denaturation of HSA in $\mathrm{pH} 3$ buffer solution and also avoid the precipitation of insoluble iron hydroxide species, which is the case if pH 7.2 PBS buffer is utilized [44,45]. The addition of $10 \mu \mathrm{M} 2$ to $20 \mu \mathrm{M}$ HSA in deionized water resulted in $\mathrm{pH}=6.5$, as verified by $\mathrm{pH}$ measurements carried out upon completion of the experiment.

The encapsulation of small molecules in HSA and other proteins has gained increasing attention in recent years since it allows the unique electronic environments inside the protein to be accessed while typically providing increased water solubility [46-48]. In our case, it was expected to lead to a fluorescent probe. As can be seen from an inspection of Figure 6, mixtures of 2 and HSA in deionized water did indeed prove fluorescent. The excitation and emission spectra for 2 after contact with HSA are shown in Figure 6. A 1:1 binding stoichiometry between 2 and HSA was inferred based on continuous variation analyses (Job plots). The addition of HSA to $10 \mu \mathrm{M} 2$ in water produced a fluorescence turn-on response in a concentration dependent manner as shown in Figure $6 c$,d under excitation at $330 \mathrm{~nm}$. A steep increase in the fluorescence emission intensity at $500 \mathrm{~nm}$ was observed upon the addition of up to 1 equivalent of HSA, while apparent saturation of the fluorescence was reached once 2 equivalents of HSA had been added. 

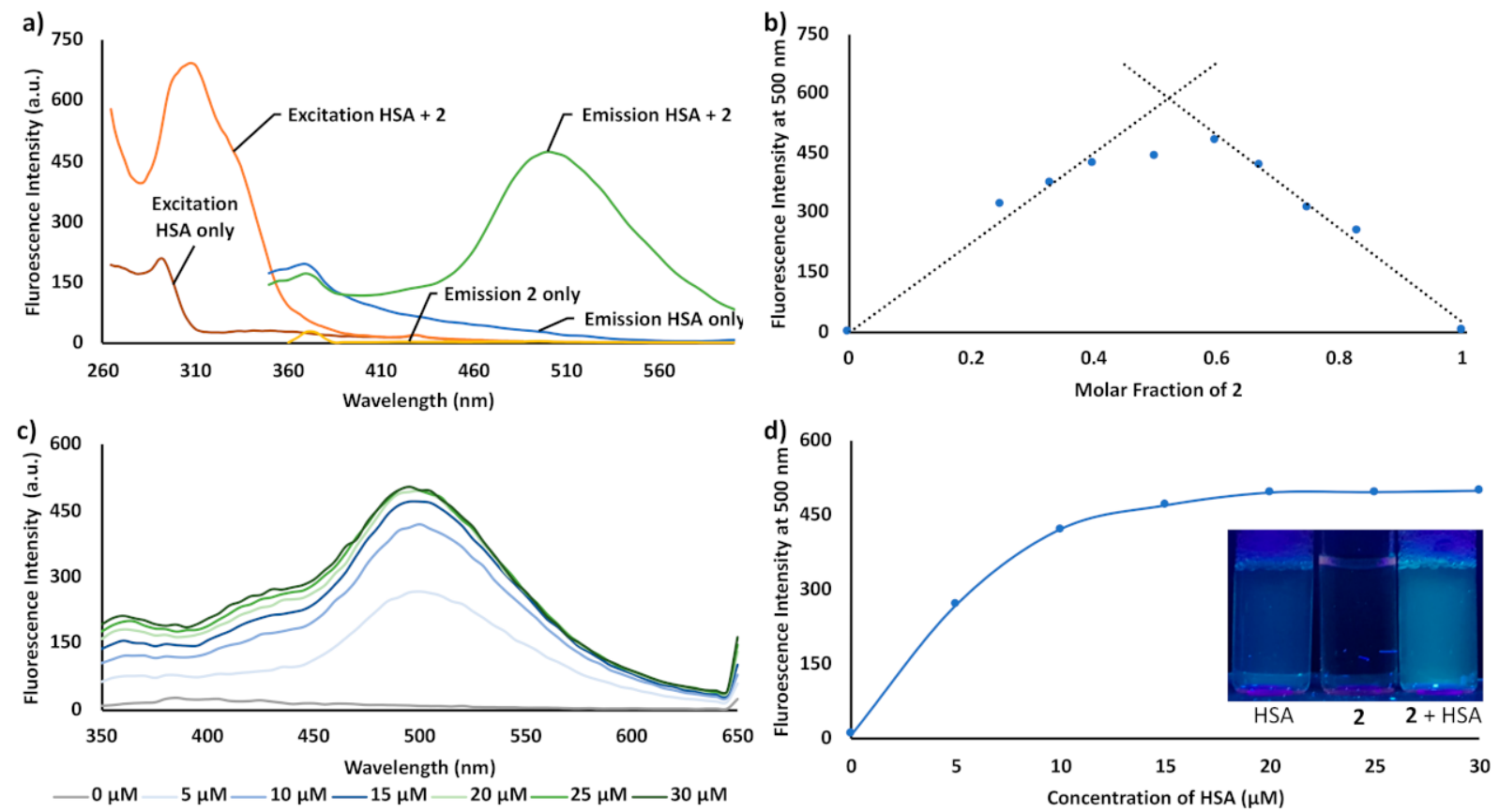

Figure 6. (a) Excitation and emission spectrum for solutions $10 \mu \mathrm{M}$ in 2, $20 \mu \mathrm{M}$ in human serum albumin (HSA), and their combination, respectively, in deionized water. (b) Job plot of 2 and HSA with the sum of both species $=30 \mu \mathrm{M}$ in deionized water. (c) Addition of human serum albumin (HSA) to a $10 \mu \mathrm{M}$ solution of $\mathbf{2}$ in deionized water. (d) Fluorescence intensity at $500 \mathrm{~nm}$ plotted against [HSA]. In the photo, the fluorescent emission of $25 \mu \mathrm{M}$ HSA, $25 \mu \mathrm{M} 2$ and both combined is shown under excitation at $350 \mathrm{~nm}$ using a hand-held UV lamp. Emission spectra were collected with excitation at $330 \mathrm{~nm}$ and excitation spectra were collected for the emission at $500 \mathrm{~nm}$. All experiments were conducted using excitation and emission slit widths of $5 \mathrm{~nm}$, respectively. The quantum yield of 2 after complexation with two equivalents HSA was calculated to be 0.0272 (reference: quinine sulfate, $0.1 \mathrm{M} \mathrm{H}_{2} \mathrm{SO}_{4}$ ), which is in agreement with other deferasirox derivatives that we have reported previously [43].

To gain insight into the interaction between 2 and HSA, a Stern-Volmer plot was created using data obtained via the incremental addition of 2 to $5 \mu \mathrm{M}$ HSA in deionized water, with the results shown in Figure 7a. Here, 2 acted as quencher for the emission of the tryptophan moieties in HSA and in accord with the Stern-Volmer Equation (1), $\left(F_{0}-F_{x}\right)-1$ was plotted over [2]:

$$
\frac{F_{0}}{F_{x}}-1=K_{S V}[Q]=k_{q} \tau_{0}[Q]
$$

With $F_{0}, F_{x}=$ fluorescence intensity at $360 \mathrm{~nm}$ in the absence $\left(F_{0}\right)$ and presence $\left(F_{x}\right)$ of quencher $Q, K_{S V}=$ Stern-Volmer quenching constant, $k_{q}=$ the bimolecular rate constant of the quenching reaction, and $\tau_{0}=$ the average fluorescent lifetime.

Rearranging Equation (1) and inserting $K_{S V}=3.4 * 10^{4} \mathrm{M}^{-1}=$ slope in Figure $7 \mathrm{a}$ and $\tau_{0}=5 * 10^{-9} \mathrm{~s}=$ fluorescent lifetime of the tryptophan moieties in HSA [49-51] yields Equation (2):

$$
k_{q}=\frac{K_{S V}}{\tau_{0}}=\frac{3.4 * 10^{4}}{5 * 10^{-9}} * \frac{\mathrm{L}}{\mathrm{mol} * \mathrm{~s}}=6.8 * 10^{12} \mathrm{M}^{-1} \mathrm{~s}^{-1}
$$



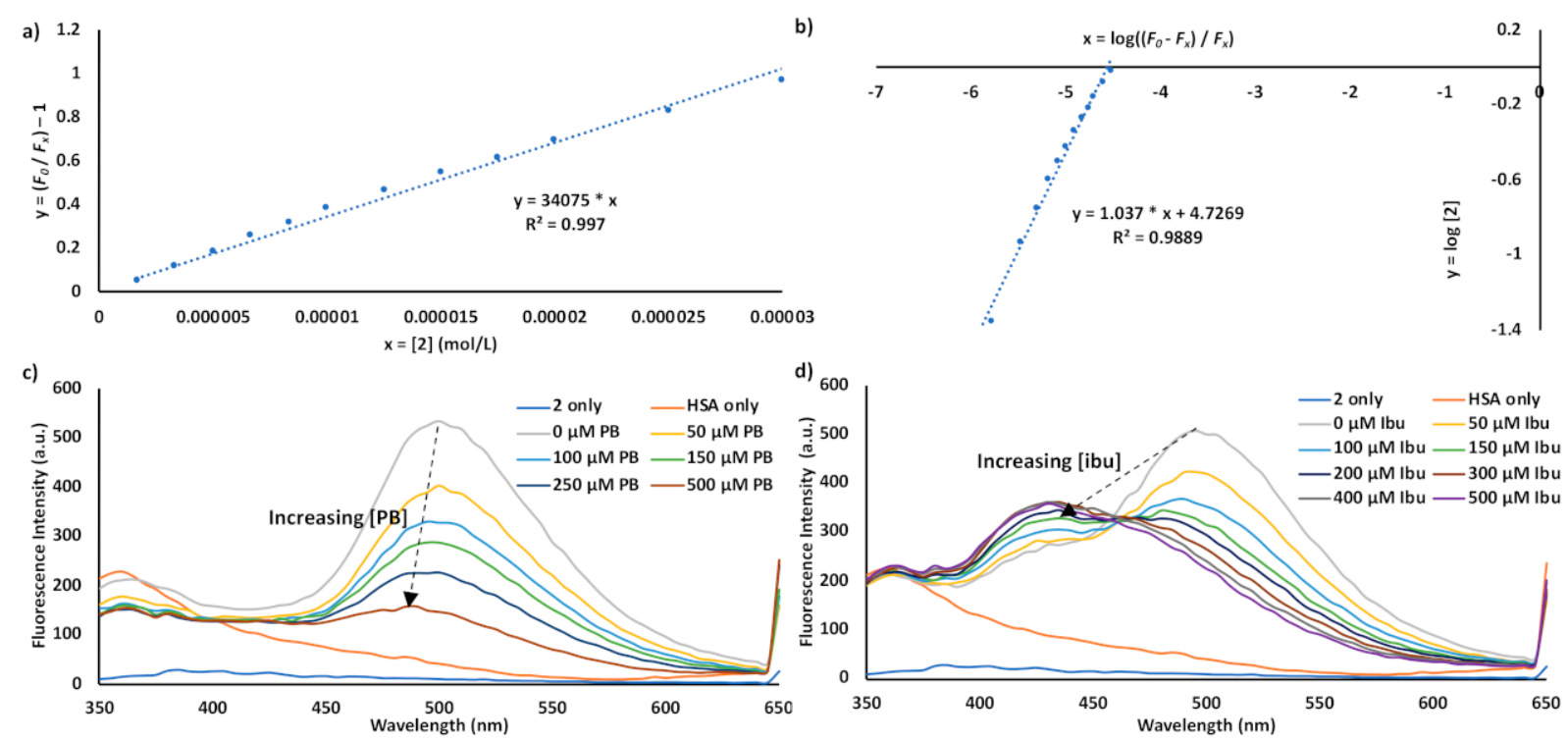

Figure 7. (a) Stern-Volmer plot for the addition of 2 into $5 \mu \mathrm{M}$ HSA in deionized water. $F_{0}, F_{x}=$ fluorescence intensity at $360 \mathrm{~nm}$ (emission of HSA) in the absence $\left(F_{0}\right)$ and presence $\left(F_{x}\right)$ of quencher 2. (b) Double logarithm plot. (c,d) Displacement studies involving plots of the fluorescence emission intensity of $10 \mu \mathrm{M}$ aqueous solutions of 2 containing $20 \mu \mathrm{M}$ HSA recorded upon addition of phenylbutazone (PB) and ibuprofen (Ibu), respectively. Experiments were conducted with excitation at $290 \mathrm{~nm}$ for (a,b) and excitation at $330 \mathrm{~nm}$ for $(\mathbf{c}, \mathbf{d})$; excitation and emission slit widths were $5 \mathrm{~nm}$, respectively, in all experiments.

From the magnitude of $k_{q}$, the interaction between 2 and HSA was deduced as involving static quenching, which is ascribed to the binding of 2 by HSA. Dynamic quenching is limited by diffusion control and therefore requires $k_{q} \leq 6 * 10^{9} \mathrm{M}^{-1} \mathrm{~s}^{-1}[49,52]$, which was not observed. Modification of the Stern-Volmer equation allowed us to estimate $n$, the number of equivalents of 2 that bind to HSA, and $K_{a}$, the binding constant between 2 and HSA [49-51], as follows:

$$
\log \left(\frac{F_{0}}{F_{x}}-1\right)=n * \log [Q]+\log K_{a}
$$

From the slope of the double logarithm plot shown in Figure 7b, a 1:1 binding stoichiometry between 2 and HSA was inferred, as well as an association constant for this interaction of $K_{a} \approx 5.0 * 10^{4} \mathrm{M}^{-1}$ from the intercept of the plot.

To gain further insights into the interactions between 2 and HSA, competition assays were performed using phenylbutazone (PB) and ibuprofen (ibu). These two drugs have been reported to bind predominantly to the IIA and IIIA regions of HSA, respectively [46]. The results shown in Figure 7c are consistent with competition between 2 and phenylbutazone. Such a finding provides support for the notion that the deferasirox derivative 2 binds to the IIA region of HSA. By contrast, the addition of ibuprofen resulted in a shift in the emission wavelength but persistence in the fluorescent emission. This latter finding is consistent with 2 remaining bound to HSA upon the addition of the IIIa region binder, ibuprofen. The cause of the observed shift in emission wavelength was not further explored over the course of this investigation.

The addition of $\mathrm{Fe}^{3+}$ to 2 after pre-complexation with HSA resulted in a loss in the fluorescence intensity at $500 \mathrm{~nm}$ in a linear, concentration dependent manner up to 1 equivalent of $\mathrm{Fe}^{3+}$ added as shown in Figure 8. Based on the titration data, the association constants $\left(K_{\mathrm{a}}\right)$ for the HSA-encapsulated ligand 2 with $\mathrm{Fe}^{3+}$ could be estimated via a nonlinear regression analysis [42]. We also calculated the limit of detection (LOD) using the following formula: $\mathrm{LOD}=3 \times \mathrm{SD}_{\mathrm{F} 0} \times\left|\mathrm{m}_{\mathrm{x}}{ }^{-1}\right|$ (where $\mathrm{SD}_{\mathrm{F} 0}=$ standard deviation of $10 \mu \mathrm{M}$ 2 mixed with $20 \mu \mathrm{M}$ HSA, and $m_{x}=$ slope of the titration curve). However, it is to be noted 
that this combination requires photoexcitation at or below $350 \mathrm{~nm}$, which could limit its utility as a biological fluorescent probe.

A standard mixture of $10 \mu \mathrm{M} 2$ and $20 \mu \mathrm{M}$ HSA was screened with a selection of nine different divalent and trivalent metal cations, and the resultant emission spectra are shown in Figure 9. We observed fluorescent quenching in the presence of $\mathrm{Cu}^{2+}, \mathrm{Fe}^{2+}$, and $\mathrm{Fe}^{3+}$, while the addition of $\mathrm{Al}^{3+}$ resulted in the emergence of a new fluorescent maximum at $430 \mathrm{~nm}$. These results lead us to suggest that 2 may be employed for the selective quantification of $\mathrm{Fe}^{3+}$ via colorimetry and combined $\mathrm{Fe}^{2+/ 3+}$ via fluorimetry; however, experimental conditions that exclude the presence of $\mathrm{Cu}^{2+}$ and $\mathrm{Al}^{3+}$ would need to be employed for the latter analyses. The observed emission increase in the presence of $\mathrm{Al}^{3+}$ will be the subject of further explorations in our lab; however, such efforts are beyond the scope of the present iron sensing study.
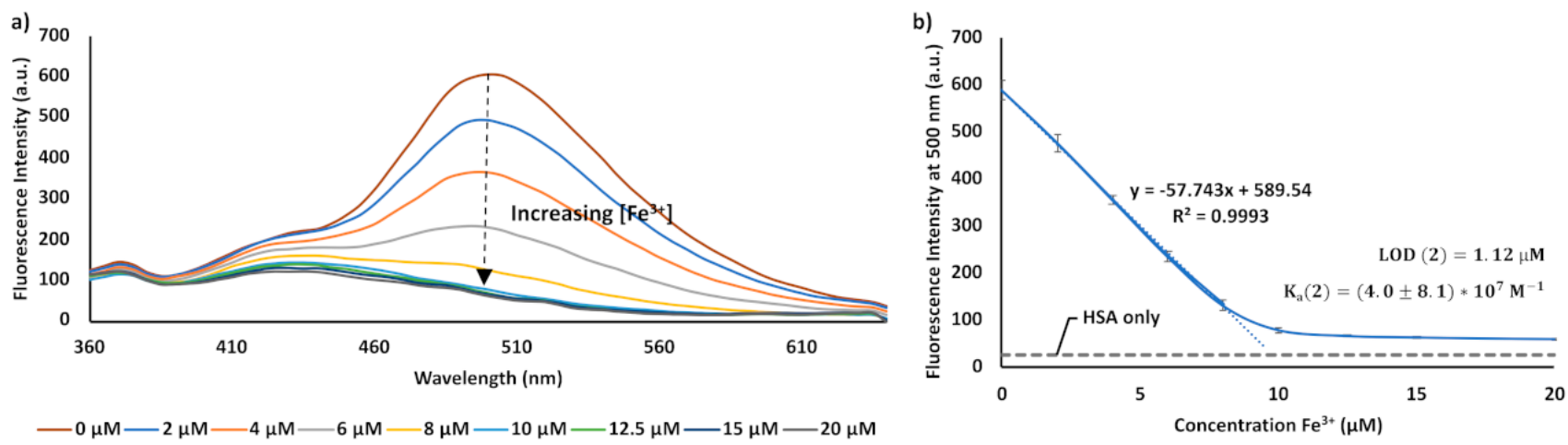

Figure 8. (a) Fluorescence quenching seen upon the addition of $\mathrm{Fe}^{3+}$ to aqueous solutions of $10 \mu \mathrm{M} 2$ containing $20 \mu \mathrm{M}$ HSA. (b) Fluorescence intensity at $500 \mathrm{~nm}$ plotted against [Fe(III)]. All experiments were conducted with excitation at $330 \mathrm{~nm}$ and with excitation and emission slit widths of $5 \mathrm{~nm}$, respectively. The inset gives the association constants $\left(K_{\mathrm{a}}\right)$ corresponding to the formation of the 1:1 complex, along with the limit of detection (LOD) determined using the following equation: $\operatorname{LOD}(\mathrm{x})=3 \times \mathrm{SD}_{\mathrm{F} 0} \times\left|\mathrm{m}_{\mathrm{x}}{ }^{-1}\right|$ where $\mathrm{SD}_{\mathrm{F} 0}=$ standard deviation of $10 \mu \mathrm{M} 2$ mixed with $20 \mu \mathrm{M}$ HSA and $\mathrm{m}_{\mathrm{x}}=$ the slope of the titration curve.
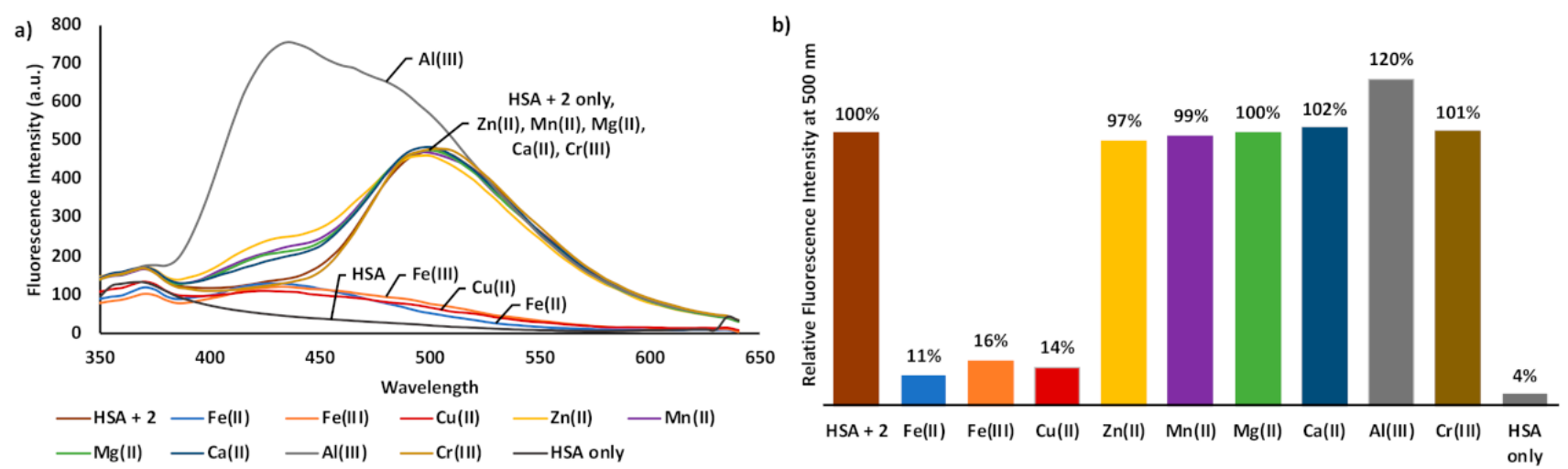

Figure 9. (a) Fluorescence emission profiles of $10 \mu \mathrm{M} 2$ and $20 \mu \mathrm{M}$ HSA in the presence of $20 \mu \mathrm{M}$ of various test di- and trivalent metal cations in deionized water. (b) Relative fluorescence intensity at $500 \mathrm{~nm}$ for each metal cation solution.

Cellular toxicity is another aspect of that needs to be considered during chemosensor development. Therefore, the in vitro cytotoxicity of $\mathbf{1}$ and $\mathbf{2}$ was evaluated in A549 lung cancer cells via a standard MTT assay with results shown in Figure 10. The A549 cell line is one with reported sensitivity to $\mathrm{Fe}^{3+}$ chelators and is one in which the cytotoxicity of $\mathbf{1}$ has been well established [53]. In accord with literature-based expectations, chelator 1 produced a concentration dependent decrease in cell viability with an $\mathrm{IC}_{50}$ value of $8.5 \mu \mathrm{M}$ 
when incubated for $72 \mathrm{~h}$. In contrast, 2 did not give rise to observable cytotoxicity in A549 cells over the full range of concentrations evaluated (i.e., $0-100 \mu \mathrm{M}$ ). The preincubation of 2 with HSA did not lead to a notable increase in the cytotoxicity.

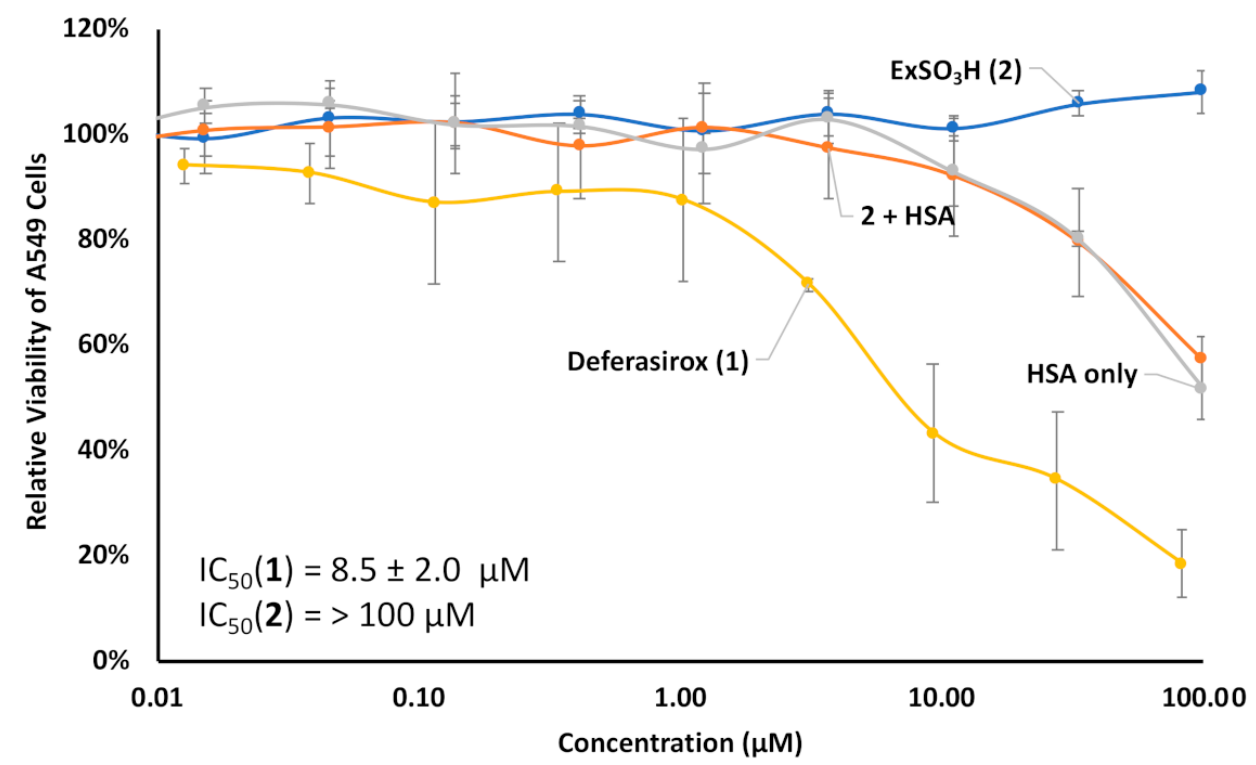

Figure 10. Cytotoxicity studies of 1 and 2 conducted in A549 cells grown in RPMI 1640 media at pH 7.2. Experiments were performed in triplicate with error bars indicating the standard deviation at each datum point. Cells were treated with different concentrations of 1, 2 and $\mathbf{2}$ pre-combined with human serum albumin (HSA), respectively, and viability was determined after an exposure time of $72 \mathrm{~h}$ via MTT assay.

To provide further context regarding the potential utility of $\mathbf{2}$ as an iron cation sensor, we have summarized previously reported $\mathrm{Fe}^{3+}$ selective chemosensors in Table 1. This table contains data for a representative set of five different chemical scaffolds that have been explored for the detection and quantification of $\mathrm{Fe}^{3+}$ in water samples. In comparison to these prior studies, $\mathbf{2}$ shows excellent LOD and an attractive $K_{\mathrm{a}}$ value. It is also appealing in that it is suitable for use under fully aqueous conditions.

Table 1. Comparison of 2 with other reported $\mathrm{Fe}^{3+}$ chemosensors.

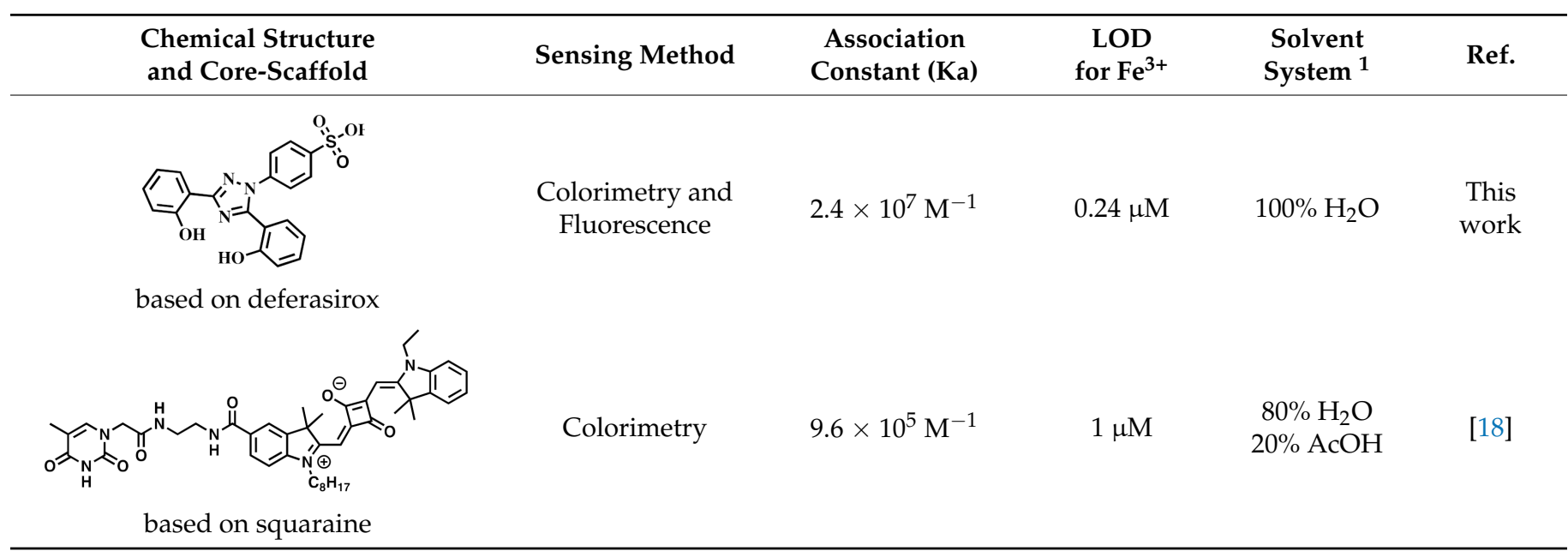


Table 1. Cont.

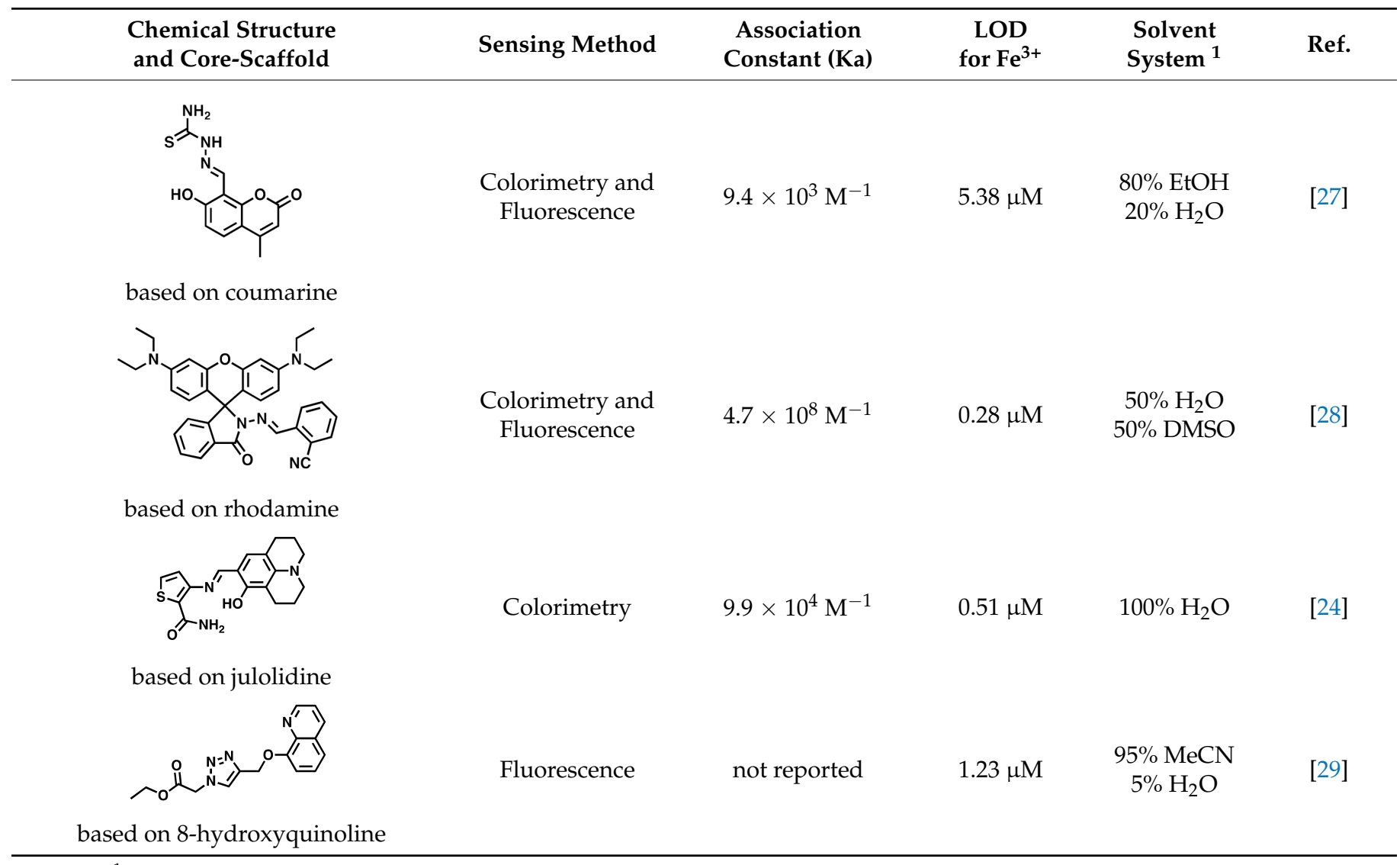

${ }^{1}$ Solvent abbreviations: $\mathrm{AcOH}=$ acetic acid, $\mathrm{EtOH}=$ ethanol, $\mathrm{H}_{2} \mathrm{O}=$ water, $\mathrm{DMSO}=$ dimethyl sulfoxide, $\mathrm{MeCN}=$ acetonitrile.

\section{Conclusions}

In this study, we have shown that $\mathrm{ExSO}_{3} \mathrm{H}$ (2), a water-soluble, non-cytotoxic, synthetically accessible and simple-to-prepare chemosensor, allows for the detection and quantification of $\mathrm{Fe}^{3+}$ in aqueous media at $\leq \mathrm{pH}$ 5. Chemosensor 2 produces a colorimetric response in the presence of $\mathrm{Fe}^{3+}$ but not other representative divalent or trivalent cations. Under acidic conditions, this colorimetric response could be used to quantify $\mathrm{Fe}^{3+}$ concentrations in real-life water samples. We further showed that treatment of 2 with the serum protein HSA, resulted in a fluorescent turn-on response that is quenched by $\mathrm{Fe}^{3+}$ in a concentration dependent manner, and that neither the free ligand 2 nor its protein-complex was cytotoxic to A549 cells.

Supplementary Materials: The following are available online at https:/ / www.mdpi.com/article / 10.3390/chemosensors9040068/s1, Scheme S1: Synthetic scheme for the preparation of 1 and 2., Figure S1: Emission profiles before and after addition of DMSO to 2 and HSA., Figure S2: Emission profiles of HSA upon addition of $\mathbf{2}$ used for the Stern-Volmer plot., Detailed synthetic procedures for all relevant compounds and the NMR and high-resolution MS spectra used for their characterization.

Author Contributions: Conceptualization, A.S. and A.C.S.; methodology, A.S., A.C.S. and Y.-Y.W.; validation, M.Y.Z., D.-Y.H.; investigation, A.S. and S.-M.H.; resources, J.L.S.; data curation, A.S.; writing—original draft preparation, A.S.; writing—review and editing, S.S., D.M.K., J.L.S.; supervision, J.L.S.; funding acquisition, J.L.S. All authors have read and agreed to the published version of the manuscript.

Funding: This work was supported by the Robert A. Welch Foundation (F-0018 to J.L.S.) and a ConTex grant provided by The University of Texas System (2019-06A to J.L.S.).

Data Availability Statement: All relevant data is contained within the article or supplementary material. 
Acknowledgments: We acknowledge use of a Bruker AVIII HD 500 with Prodigy liquid nitrogen cryoprobe supported by NIH grant 1 S10 OD021508.

Conflicts of Interest: The authors declare no conflict of interest.

\section{References}

1. World Health Organization; International Programme on Chemical Safety. Guidelines for Drinking-Water Quality: Health Criteria and Other Supporting Information, 2nd ed.; WHO: Geneva, Switzerland, 1996; Volume 2.

2. Pesavento, M.; Alberti, G.; Biesuz, R. Analytical methods for determination of free metal ion concentration, labile species fraction and metal complexation capacity of environmental waters: A review. Anal. Chim. Acta 2009, 631, 129-141. [CrossRef] [PubMed]

3. Que, E.L.; Domaille, D.W.; Chang, C.J. Metals in Neurobiology: Probing Their Chemistry and Biology with Molecular Imaging. Chem. Rev. 2008, 108, 1517-1549. [CrossRef] [PubMed]

4. Steinbrueck, A.; Sedgwick, A.C.; Brewster, J.T.; Yan, K.-C.; Shang, Y.; Knoll, D.M.; Vargas-Zúñiga, G.I.; He, X.-P.; Tian, H.; Sessler, J.L. Transition metal chelators, pro-chelators, and ionophores as small molecule cancer chemotherapeutic agents. Chem. Soc. Rev. 2020, 49, 3726-3747. [CrossRef] [PubMed]

5. Richardson, D.R.; Kalinowski, D.S.; Lau, S.; Jansson, P.J.; Lovejoy, D.B. Cancer cell iron metabolism and the development of potent iron chelators as anti-tumour agents. Biochim. Biophys. Acta Gen. Subj. 2009, 1790, 702-717. [CrossRef]

6. Abbaspour, N.; Hurrell, R.; Kelishadi, R. Review on iron and its importance for human health. J. Res. Med. Sci. 2014, 19, 164-174. [PubMed]

7. Fujii, M.; Imaoka, A.; Yoshimura, C.; Waite, T.D. Effects of molecular composition of natural organic matter on ferric iron complexation at circumneutral pH. Environ. Sci. Technol. 2014, 48, 4414-4424. [CrossRef]

8. Schwertmann, U. Solubility and dissolution of iron oxides. Plant Soil 1991, 130, 1-25. [CrossRef]

9. Arpadjan, S.; Tsekova, K.; Petrova, P.; Knutsson, J. Field sampling, speciation and determination of dissolved iron (II) and iron (III) in waters. Bulg. Chem. Commun. 2012, 44, 299-306. [CrossRef]

10. Vickackaite, V.; Tautkus, S.; Kazlauskas, R. Determination of Heavy Metals in Natural Waters by Flame Atomic Absorption Spectrometry. Chem. Anal. 1996, 41, 483-488.

11. Shamspur, T.; Sheikhshoaie, I.; Mashhadizadeh, M.H. Flame atomic absorption spectroscopy (FAAS) determination of iron(III) after preconcentration on to modified analcime zeolite with 5-((4-nitrophenylazo)-N-( $2^{\prime}, 4^{\prime}$-dimethoxyphenyl))salicylaldimine by column method. J. Anal. At. Spectrom. 2005, 20, 476-478. [CrossRef]

12. Yildiz, O.; Citak, D.; Tuzen, M.; Soylak, M. Determination of copper, lead and iron in water and food samples after column solid phase extraction using 1-phenylthiosemicarbazide on Dowex Optipore L-493 resin. Food Chem. Toxicol. 2011, 49, 458-463. [CrossRef] [PubMed]

13. Yan, X.P.; Hendry, J.M.; Kerrich, R. Speciation of dissolved iron(III) and iron(II) in water by on-line coupling of flow injection separation and preconcentration with inductively coupled plasma mass spectrometry. Anal. Chem. 2000, 72, 1879-1884. [CrossRef] [PubMed]

14. Hu, Q. Simultaneous Separation and Quantification of Iron and Transition Species Using LC-ICP-MS. Am. J. Anal. Chem. 2011, 2, 675-682. [CrossRef]

15. Pomazal, K.; Prohaska, C.; Steffan, I.; Reich, G.; Huber, J.F.K. Determination of Cu, Fe, Mn, and Zn in blood fractions by SEC-HPLC-ICP-AES coupling. Analyst 1999, 124, 657-663. [CrossRef] [PubMed]

16. Becuwe, M.; Rouge, P.; Gervais, C.; Courty, M.; Dassonville-Klimpt, A.; Sonnet, P.; Baudrin, E. A new sensitive organic/inorganic hybrid material based on titanium oxide for the potentiometric detection of iron(III). J. Colloid Interface Sci. 2012, 388, 130-136. [CrossRef] [PubMed]

17. van den Berg, C.M.G. Chemical speciation of iron in seawater by cathodic stripping voltammetry with dihydroxynaphthalene. Anal. Chem. 2006, 78, 156-163. [CrossRef] [PubMed]

18. Liu, X.; Li, N.; Xu, M.M.; Wang, J.; Jiang, C.; Song, G.; Wang, Y. Specific colorimetric detection of $\mathrm{Fe}^{3+}$ ions in aqueous solution by squaraine-based chemosensor. RSC Adv. 2018, 8, 34860-34866. [CrossRef]

19. Adebayo, B.K.; Ayejuyo, S.; Okoro, H.K.; Ximba, B.J. Spectrophotometric determination of iron (III) in tap water using 8hydoxyquinoline as a chromogenic reagent. Afr. J. Biotechnol. 2011, 10, 16051-16057. [CrossRef]

20. Lashgari, N.; Badiei, A.; Mohammadi Ziarani, G. A Fluorescent Sensor for Al(III) and Colorimetric Sensor for Fe(III) and Fe(II) Based on a Novel 8-Hydroxyquinoline Derivative. J. Fluoresc. 2016, 26, 1885-1894. [CrossRef]

21. Harathi, J.; Thenmozhi, K. AIE-active Schiff base compounds as fluorescent probes for the highly sensitive and selective detection of $\mathrm{Fe}^{3+}$ ions. Mater. Chem. Front. 2020, 4, 1471-1482. [CrossRef]

22. Wei, D.; Sun, Y.; Yin, J.; Wei, G.; Du, Y. Design and application of $\mathrm{Fe}^{3+}$ probe for "naked-eye" colorimetric detection in fully aqueous system. Sens. Actuators B Chem. 2011, 160, 1316-1321. [CrossRef]

23. Nizar, S.A.; Kobayashi, T.; Mohd Suah, F.B. An aminonaphthalene-based colorimetric and fluorescent sensor for selective recognition of $\mathrm{Fe}^{3+}$ in water. Luminescence 2020, 35, 1286-1295. [CrossRef]

24. Jang, H.J.; Ahn, H.M.; Kim, M.S.; Kim, C. A highly selective colorimetric chemosensor for sequential detection of Fe ${ }^{3+}$ and pyrophosphate in aqueous solution. Tetrahedron 2017, 73, 6624-6631. [CrossRef]

25. Wang, W.; Wei, J.; Liu, H.; Liu, Q.; Gao, Y. A novel colorimetric chemosensor based on quinoline for the sequential detection of $\mathrm{Fe}^{3+}$ and PPi in aqueous solution. Tetrahedron Lett. 2017, 58, 1025-1029. [CrossRef] 
26. Kao, M.H.; Wan, C.F.; Wu, A.T. A selective colorimetric chemosensor for Fe ${ }^{3+}$. Luminescence 2017, 32, 1561-1566. [CrossRef]

27. Wang, L.; Li, W.; Zhi, W.; Huang, Y.; Han, J.; Wang, Y.; Ren, Y.; Ni, L. A new coumarin schiff based fluorescent-colorimetric chemosensor for dual monitoring of $\mathrm{Zn}^{2+}$ and $\mathrm{Fe}^{3+}$ in different solutions: An application to bio-imaging. Sens. Actuators B Chem. 2018, 260, 243-254. [CrossRef]

28. Zhou, F.; Leng, T.H.; Liu, Y.J.; Wang, C.Y.; Shi, P.; Zhu, W.H. Water-soluble rhodamine-based chemosensor for Fe ${ }^{3+}$ with high sensitivity, selectivity and anti-interference capacity and its imaging application in living cells. Dye. Pigment. 2017, 142, 429-436. [CrossRef]

29. Hao, E.; Meng, T.; Zhang, M.; Pang, W.; Zhou, Y.; Jiao, L. Solvent dependent fluorescent properties of a 1,2,3-triazole linked 8-hydroxyquinoline chemosensor: Tunable detection from zinc(II) to iron(III) in the CH3CN/H2O system. J. Phys. Chem. A 2011, 115, 8234-8241. [CrossRef]

30. Liu, S.R.; Wu, S.P. New water-soluble highly selective fluorescent chemosensor for Fe (III) ions and its application to living cell imaging. Sens. Actuators B Chem. 2012, 171-172, 1110-1116. [CrossRef]

31. Suryawanshi, S.B.; Mahajan, P.G.; Bodake, A.J.; Kolekar, G.B.; Patil, S.R. Carbazole based nanoprobe for selective recognition of $\mathrm{Fe} 3+$ ion in aqueous medium: Spectroscopic insight. Spectrochim. Acta Part A Mol. Biomol. Spectrosc. 2017, 183, 232-238. [CrossRef]

32. Chen, Z.; Lu, D.; Zhang, G.; Yang, J.; Dong, C.; Shuang, S. Glutathione capped silver nanoclusters-based fluorescent probe for highly sensitive detection of $\mathrm{Fe}^{3+}$. Sens. Actuators B Chem. 2014, 202, 631-637. [CrossRef]

33. Vanjare, B.D.; Mahajan, P.G.; Hong, S.K.; Lee, K.H. Discriminating Chemosensor for Detection of Fe ${ }^{3+}$ in Aqueous Media by Fluorescence Quenching Methodology. Bull. Korean Chem. Soc. 2018, 39, 631-637. [CrossRef]

34. Dong, L.; Wu, C.; Zeng, X.; Mu, L.; Xue, S.F.; Tao, Z.; Zhang, J.X. The synthesis of a rhodamine B schiff-base chemosensor and recognition properties for $\mathrm{Fe}^{3+}$ in neutral ethanol aqueous solution. Sens. Actuators B Chem. 2010, 145, 433-437. [CrossRef]

35. Gupta, R.S.; Dudani, A.K. Species-specific differences in the toxicity of rhodamine 123 toward cultured mammalian cells. J. Cell. Physiol. 1987, 130, 321-327. [CrossRef] [PubMed]

36. Steinhauser, S.; Heinz, U.; Bartholomä, M.; Weyhermüller, T.; Nick, H.; Hegetschweiler, K. Complex Formation of ICL670 and Related Ligands with Fe III and Fe II. Eur. J. Inorg. Chem. 2004, 2004, 4177-4192. [CrossRef]

37. Rouge, P.; Dassonville-Klimpt, A.; Cézard, C.; Boudesocque, S.; Ourouda, R.; Amant, C.; Gaboriau, F.; Forfar, I.; Guillon, J.; Guillon, E.; et al. Synthesis, physicochemical studies, molecular dynamics simulations, and metal-ion-dependent antiproliferative and antiangiogenic properties of cone ICL670-substituted calix[4]arenes. Chempluschem 2012, 77, 1001-1016. [CrossRef]

38. Jo, T.G.; Jung, J.M.; Han, J.; Lim, M.H.; Kim, C. A single fluorescent chemosensor for multiple targets of $\mathrm{Cu}^{2+}, \mathrm{Fe}^{2+} /{ }^{3+}$ and $\mathrm{Al}^{3+}$ in living cells and a near-perfect aqueous solution. RSC Adv. 2017, 7, 28723-28732. [CrossRef]

39. Shi, B.B.; Zhang, P.; Wei, T.B.; Yao, H.; Lin, Q.; Zhang, Y.M. Highly selective fluorescent sensing for CN- in water: Utilization of the supramolecular self-assembly. Chem. Commun. 2013, 49, 7812-7814. [CrossRef]

40. Simpson, P.V.; Schmidt, C.; Ott, I.; Bruhn, H.; Schatzschneider, U. Synthesis, Cellular Uptake and Biological Activity Against Pathogenic Microorganisms and Cancer Cells of Rhodium and Iridium N-Heterocyclic Carbene Complexes Bearing Charged Substituents. Eur. J. Inorg. Chem. 2013, 2013, 5547-5554. [CrossRef]

41. Peng, Y.; Shi, Y.; Zhang, H.; Mine, Y.; Tsao, R. Anti-inflammatory and anti-oxidative activities of daidzein and its sulfonic acid ester derivatives. J. Funct. Foods 2017, 35, 635-640. [CrossRef]

42. Thordarson, P. Determining association constants from titration experiments in supramolecular chemistry. Chem. Soc. Rev. 2011, 40, 1305-1323. [CrossRef]

43. Sedgwick, A.C.; Yan, K.-C.; Mangel, D.N.; Shang, Y.; Steinbrueck, A.; Han, H.-H.; Brewster, J.T.; Hu, X.-L.; Snelson, D.W.; Lynch, V.M.; et al. Deferasirox (ExJade): An FDA-Approved AIEgen Platform with Unique Photophysical Properties. J. Am. Chem. Soc. 2021, 143, 1278-1283. [CrossRef]

44. Neurath, H.; Greenstein, J.P.; Putnam, F.W.; Erickson, J.O. The chemistry of protein denaturation. Chem. Rev. 1944, $34,157-265$. [CrossRef]

45. Lee, J.Y.; Hirose, M. Partially folded state of the disulfide-reduced form of human serum albumin as an intermediate for reversible denaturation. J. Biol. Chem. 1992, 267, 14753-14758. [CrossRef]

46. Han, H.H.; Sedgwick, A.C.; Shang, Y.; Li, N.; Liu, T.; Li, B.H.; Yu, K.; Zang, Y.; Brewster, J.T.; Odyniec, M.L.; et al. Protein encapsulation: A new approach for improving the capability of small-molecule fluorogenic probes. Chem. Sci. 2020, 11, 1107-1113. [CrossRef]

47. Edwardson, T.G.W.; Tetter, S.; Hilvert, D. Two-tier supramolecular encapsulation of small molecules in a protein cage. Nat. Commun. 2020, 11, 5410. [CrossRef] [PubMed]

48. Jia, Z.; Han, H.-H.; Sedgwick, A.C.; Williams, G.T.; Gwynne, L.; Brewster, J.T.; Bull, S.D.; Jenkins, A.T.A.; He, X.-P.; Schönherr, H.; et al. Protein Encapsulation: A Nanocarrier Approach to the Fluorescence Imaging of an Enzyme-Based Biomarker. Front. Chem. 2020, 8 , 389. [CrossRef] [PubMed]

49. Sen, S.; Perrin, M.W.; Sedgwick, A.C.; Dunsky, E.Y.; Lynch, V.M.; He, X.P.; Sessler, J.L.; Arambula, J.F. Toward multifunctional anticancer therapeutics: Post-synthetic carbonate functionalisation of asymmetric Au(i) bis-N-heterocyclic carbenes. Chem. Commun. 2020, 56, 7877-7880. [CrossRef] [PubMed] 
50. Nusrat, S.; Siddiqi, M.K.; Zaman, M.; Zaidi, N.; Ajmal, M.R.; Alam, P.; Qadeer, A.; Abdelhameed, A.S.; Khan, R.H. A comprehensive spectroscopic and computational investigation to probe the interaction of antineoplastic drug nordihydroguaiaretic acid with serum albumins. PLOS ONE 2016, 11, e0158833. [CrossRef]

51. Lakowicz, J.R. Principles of fluorescence spectroscopy Chapter 4: Time-Domain Lifetime Measurements. In Principles of Fluorescence Spectroscopy; Springer: Boston, MA, USA, 2006; pp. 97-156. ISBN 0387312781.

52. Calvert, J.G.; Pitts, J.N. Photochemistry; John Wiley \& Sons, Inc.: Hoboken, NJ, USA, 1966; pp. 626-627. ISBN 0471130907.

53. Loza-Rosas, S.A.; Vázquez-Salgado, A.M.; Rivero, K.I.; Negrón, L.J.; Delgado, Y.; Benjamín-Rivera, J.A.; Vázquez-Maldonado, A.L.; Parks, T.B.; Munet-Colón, C.; Tinoco, A.D. Expanding the Therapeutic Potential of the Iron Chelator Deferasirox in the Development of Aqueous Stable Ti(IV) Anticancer Complexes. Inorg. Chem. 2017, 56, 7788-7802. [CrossRef] [PubMed] 